\title{
Influence of humic acid on growth and yield of strawberry cv. Chandler
}

\author{
Izhar Ullah ${ }^{1 *}$, Muhammad Sajid ${ }^{1}$, Syed Tanveer Shah ${ }^{1}$, Sajid Khan ${ }^{1}$, \\ Zafar Iqbal ${ }^{2}$, Fazal-i-Wahid ${ }^{1}$, Ehtesham ul Hassan ${ }^{3}$, Sayyed Hamad \\ Ahmad Shah ${ }^{1}$ and Rahmatullah Khan ${ }^{1}$ \\ 1. Department of Horticulture, The University of Agriculture Peshawar-Pakistan \\ 2. Department of Agricultural Chemistry, The University of Agriculture Peshawar-Pakistan \\ 3. Food and Agriculture Organization Islamabad-Pakistan \\ *Corresponding author's email: $\underline{\text { izharhorticons361@aup.edu.pk }}$ \\ Citation \\ Izhar Ullah, Muhammad Sajid, Syed Tanveer Shah, Sajid Khan, Zafar Iqbal, Fazal-i-Wahid, Ehtisham ul Hassan, \\ Sayyed Hamad Ahmad Shah and Rahmatullah Khan. Influence of humic acid on growth and yield of strawberry cv. \\ chandler. Pure and Applied Biology. Vol. 6, Issue 4, pp1171-1176. http://dx.doi.org/10.19045/bspab.2017.600125
}

\begin{tabular}{llll}
\hline Received: 29/04/2017 & Revised: 18/08/2017 & Accepted: 12/09/2017 & Online First: 15/09/2017
\end{tabular}

\section{Abstract}

A study on "Influence of humic acid on growth and yield of strawberry cv. Chandler" was conducted at Newly Development Horticultural Farm, The University of Agriculture Peshawar, Pakistan during 2014. The experiment was carried out using Randomized Complete Block design (RCBD) with one factor replicated thrice. Three levels of humic acid (1.5, 3.0 and 4.5ml $\mathrm{L}^{-1}$ ) were sprayed on strawberry plant after 30 days of transplanting. The data were recorded on various growth and fruit yield of strawberry at various stages. The analyzed data showed that more number of fruits (28.3) plant $^{-1}$, total carotenoids $\left(17.84 \mathrm{mgg}^{-1}\right)$, total lycopene content $\left(0.0244 \mathrm{mgg}^{-1}\right)$ were recorded at $3 \mathrm{mlL}^{-1}$ humic acid and minimum percent fruit waste $(0)$ was recorded with humic acid at $4.5 \mathrm{mlL}^{-1}$, while titratable acidity was found non-significant. It was concluded from the above results that the strawberry cv. Chandler could be sprayed with 3.0 $\mathrm{mlL}^{-1}$ of humic acid in order to obtain better growth and quality fruit production under the agroclimatic condition of Peshawar.

Keywords: Fragaria ananassa Dutch; Straw; Humic acid; Fertility; Carotenoid; Lycopene

\section{Introduction}

Strawberry (Fragaria ananassa belongs to family Rosaceae, subfamily Rosoideae. The garden strawberry was first bred in Brittany, France, in the 1750s which is derived from a cross between $F$. virginiana from Eastern North America and $F$. chiloensis from Chile and Argentina .The word "straw" referred to the practice of covering the plant with straw to protect it from freezing [1]. Strawberries are mostly grown in many parts of the world including Japan, USA, Mexico, Italy and
Germany. In Pakistan strawberry are cultivated in plains of Ghotki, Panu Akil, Ranipur, Shaheed Benazirabad, Gilgit, Chitral, Kaghan, Kohistan, Swat, Mingora, Multan, Narowal, Bhawalpur, Chistian, Sialkot and Faisalabad. In Khyber Pakhtunkhwa, it grows in hilly areas especially in Swat and Murree and also in plain areas of Peshawar in the month of October. 274 tons strawberry on 78 hectares land was produced during the year 2008 to 2009 [2]. The climatic condition of Pakistan 
is very suitable for the cultivation of strawberry. Because of its low chilling requirement therefore it is cultivated in temperate and semitropical regions. The ideal temperature for strawberry growth is between $20-26{ }^{\circ} \mathrm{C}$ and above $30^{\circ} \mathrm{C}$ growth slows dramatically and above $35^{\circ} \mathrm{C}$ damage starts [3]. Strawberries are mainly produced through runners [4]. It starts flowering at the end of February and fruiting in the month of March that continues till April and start runners formation in May when the temperature increased [5]. Strawberry performs better on garden soil having a $\mathrm{pH}$ of 5.5-6.5. They are very susceptible to nutrient deficiency and require good nutrition for better yields of high quality berries and for disease and insect control [6]. Humic matter is formed through the chemical and biological humification of plant and animal matter and through the biological activities of microorganisms [7]. Humic acid (HA) contains organic C (51$57 \%), \mathrm{N}(4-6 \%)$ and $\mathrm{P}(0.2-1.0 \%)[8,9]$. Humic acid improved the physio chemical and biological properties of the soils [8], promotion of root development [10]. Humic compounds improve soil structure, increase soil microbial population, increase soil cation exchange capacity and providing some specific materials for plant root indirectly by providing macro and microminerals, leading to the increase of soil fertility [11]. Under water stress, foliar fertilization with humic molecules increased leaf water retention, photosynthetic and antioxidant metabolism [12]. Keeping in view the problems related to strawberry growth, yield and importance of humic acid, a study on "Influence of humic acid on growth and yield of strawberry cv. Chandler" was carried out with the objective to evaluate the optimum concentration of humic acid for better growth and yield of strawberry cultivar.

\section{Materials and methods}

A study on "Influence of Humic acid on growth and yield of strawberry cv. Chandler" was carried out at Newly Development Horticulture Farm, The University of Agriculture Peshawar, Pakistan in October 2014.

\section{Experimental design and treatment combination}

The experiment was laid out using Randomized Complete Block Design (RCBD) with one factor replicated three times. Strawberry plants were sprayed with humic acid $\left(1.5,3.0\right.$ and $\left.4.5 \mathrm{mlL}^{-1}\right)$ after 30 days of transplantation.

\section{Planting materials}

The field was prepared and divided into 12 Plots. Each plot size was $36 \mathrm{ft}^{2}\left(3.34 \mathrm{~m}^{2}\right)$ and in each plot had 32 plants of strawberry. The runners of strawberry $\mathrm{cv}$. Chandler were brought and planted in the month of October, 2014 on ridges at a distance of $1 \mathrm{ft}$ $(30 \mathrm{~cm})$ between plant to plant and $2 \mathrm{ft}$ $(60 \mathrm{~cm})$ between row to row. Hoeing, weeding and irrigation were done on the basis of their needs and wheat straw was used as mulch for protection from frost.

\section{Preparation of humic acid solution and its} application time

A solution of one liter was made from $18 \%$ liquid humic acid for all treatment levels and then foliar spray of humic acid were occure three times after 30 days of transplantation on each experimental plot with duration of 10 days interval.

The data for following attributes of strawberry was recorded accordingly.

Number of fruits plant ${ }^{-1}$

Fruit were counted by taking randomly five plants, and the average was calculated.

\section{Percent fruit waste}

Fruits were selected in each treatment on the basis of visual observation of fruits in each picking and were determined with the help of following formula. 
Fruit waste $\%=\frac{\text { undesirable fruit }}{\text { Total no of fruit }} \times 100$

\section{Percent titratable acidity}

Percent titratable acidity of strawberry juice was determined by the standard method of [13].

Total carotenoids and lycopene ( $\left.\mathrm{mgg}^{-1}\right)$

Total carotenoids and lycopene were estimated by the method described by Zakaria et al. [14].

\section{Data analysis}

Randomized Complete Block Design (RCBD) was used for data analysis and least significant differences test (LSD) at 5\% was used for mean separation when F- value was significant. Statistical software Statistix (8.1) was used for calculating ANOVA and LSD value [15].

\section{Results and discussion}

Number of fruits plant ${ }^{-1}$

Number of fruits plant ${ }^{-1}$ was significantly influenced by different concentration of humic acid (Table 1). The mean data table showed that highest number of fruits (28.3) was noted in plant with the application of humic acid at $3 \mathrm{mlL}^{-1}$ followed by (26.3) number of fruits at $1.5 \mathrm{ml} \mathrm{L}^{-1}$ humic acid.
The lowest number of fruits (22.6) was recorded in control treatment.

Humic acid significantly increase the rate of photosynthesis, respiration and plant harmone like activity in plants as result flower concentration increase which boost up fruit ratio in plant [16]. [17] reported that humic acid contain cytokinins and their application outcome in increased endogenous cytokinin and auxin levels which possibly leading to improve growth of plant as result number of berries per plant increases. [18] Suggested that foliar application of humic acid led to improvement of quantitative and qualitative characteristics of strawberry (chlorophyll content, fruit number, total yield of plant, TSS and fruit firmness).Similarly the results are in line with the findings of [19] who treated strawberry plant with humic acid and vermicost and found a significant effect of number of fruits. [20] Investigated the effect of humic acid and sea weed extract on cucumber and found a significant effect of number of fruits. [21] studied effect of humic acid from different source on growth of green house plants and found a significant effect of number of fruits.

Table 1. Humic acid influenced number of fruit plant $^{-1}$, fruit waste (\%), titratable acidity (\%), total carotenoid ( $\left.\mathrm{mg} \mathrm{g}^{-1}\right)$ and total lycopene content ( $\left.\mathrm{mg} \mathrm{g}^{-1}\right)$ of Strawberry $\mathrm{Cv}$. Chandler

\begin{tabular}{|c|l|l|l|l|l|}
\hline Humic acid $\left(\mathbf{m L L}^{-1}\right)$ & NOFP & PFW & TA & TC & TL \\
\hline 0 & $22.6 \mathrm{bc}$ & $1.33 \mathrm{~b}$ & 0.86 & $15.27 \mathrm{a}$ & $0.0220 \mathrm{a}$ \\
\hline 1.5 & $26.3 \mathrm{ab}$ & $12.33 \mathrm{a}$ & 0.84 & $16.61 \mathrm{ab}$ & $0.0243 \mathrm{a}$ \\
\hline 3 & $28.3 \mathrm{a}$ & $4.33 \mathrm{~b}$ & 0.75 & $17.84 \mathrm{ab}$ & $0.0244 \mathrm{a}$ \\
\hline 4.5 & $21 \mathrm{c}$ & $0 \mathrm{~b}$ & 0.62 & $15.58 \mathrm{~b}$ & $0.0019 \mathrm{~b}$ \\
\hline LSD at $\mathrm{P} \leq 0.05$ & 3.98 & 7.67 & NS & 0.07 & 0.005 \\
\hline
\end{tabular}

NOFP: Number of fruits plant ${ }^{-1}$; PFW: Percent fruit waste; TA: Titratable acidity; TC: Total carotenoids; TL: Total Lycopene. Means followed by similar letter(s) are statistically at par with each at 5\% levels of significance

\section{Percent fruit waste}

Percent fruit waste was significantly influenced by foliar spray of humic acid. The mean data analyzed that maximum percent fruit waste (12) was observed in plants treated with humic acid at $\left(1.5 \mathrm{mlL}^{-1}\right)$ followed by percent fruit waste (4) with humic acid at $3 \mathrm{mlL}^{-1}$. While minimum percent fruit waste (0) was observed in plants treated with humic acid at $4.5 \mathrm{mlL}^{-1}$. 
The results are in relation with findings of [22] who treated strawberry with humic acid between bloom and fruit harvest and found a significant role of humic acid on fruit waste

\section{Percent titratable acidity}

Data regarding percent titratable acidity shows that different level of humic acid had non-significant effect on the percent titratable acidity of strawberry fruit (Table 1).

\section{Total carotenoids $\left(\mathrm{mgg}^{-1}\right)$}

Total carotenoids were significantly influenced by foliar application of humic acid (Table 1). The mean data revealed that highest carotenoids content $\left(17.84 \mathrm{mgg}^{-1}\right)$ was recorded in plant fruit treated with humic acid at $3 \mathrm{mlL}^{-1}$ followed by carotenoids content $\left(16.61 \mathrm{mgg}^{-1}\right)$ with humic acid at $\left(1.5 \mathrm{mlL}^{-1}\right)$.While the lowest carotenoids content $\left(15.27 \mathrm{mgg}^{-1}\right)$ was observed in control treatment).

The increase in total carotenoid content observed in the study could be the results of the significant increases in beta carotene, total xanthophyll and lycopene contents in response to HA treatment [23]. The results are in relation with the findings of [24] who found a direct effect of fertilizer on carotenoid synthesis where potassium, deficiency is closely associated with higher level of beta carotene and decrease in lycopene. [25] reported that humic acid application affected pepper growth and fruit characteristics and had positive influence on quantitative and qualitative traits of pepper plant. [26] stated that humic acid application had positive influence on qualitative traits of marigold (Calendula officinalis L.). [27] reported that total carotenoids increased with application vermicompost treatments. [28] observed a higher total carotenoids in organically grown sweet peppers than in integrated and conventional peppers.

\section{Total lycopene $\left(\mathrm{mgg}^{-1}\right)$}

Foliar spray of humic acid significantly influenced total lycopene content of strawberry (Table 1). The mean data analyzed that that the highest lycopene content $\left(0.0244 \mathrm{mgg}^{-1}\right)$ was recorded in plants treated with humic acid at $3.0 \mathrm{mlL}^{-1}$ followed by lycopene content $\left(0.0243 \mathrm{mgg}^{-1}\right)$ at $1.5 \mathrm{mlL}^{-1}$ humic acid. While lowest lycopene content $\left(0.0019 \mathrm{mgg}^{-1}\right) \quad$ was recorded in plants treated with humic acid at $4.5 \mathrm{mlL}^{-1}$.

The significant difference among means of total lycopene content might be due to significant response of humic acid on carotenoids content. In support of our findings, [29] have reported an increase in lycopene and beta carotene contents of pepper fruit in response to HA application.

\section{Conclusion and recommendations}

It was concluded from the above results that humic acid significantly influenced most of the studied attributes of strawberry. Hence, humic acid could be applied after 30 days of transplantation of strawberry runners at 3 $\mathrm{mlL}^{-1}$ for better quality production of strawberry fruit in the agro climatic region of Peshawar valley.

\section{Authors' contributions}

Designed the experiment: M Sajid, Collection of field data: S Khan \& EU Hasan, Statistical anlaysis of the data; ST Shah, Z Iqbal \& R Khan, Wrote the paper: ST Shah, FI Wahid \& SHA Shah.

\section{References}

1. Darrow GM (1966). The Strawberry. Holt, Rinehart, and Winston. Canada.

2. GOP (2009). Fruits, vegetables and condiments statistics of Pakistan. Ministry Food Agric Econ Div pp. 1-2.

3. Darrow GM \& Waldo GF (1934). Responses of strawberry varieties and species to duration of the daily light period. USDA Technical Bulletin 453: Washington.

4. Emeritus DC (1997). Strawberry Plant Structure and Growth Habit. E. Barclay Poling NC State. 
5. Amin NU (1996). Evaluation of different strawberry cultivars for off-season production under plastic tunnels. P.3 M.Sc (Hons) Thesis, Department of Horticulture KPK Agricultural University Peshawar.

6. Larry Z (2012). Strawberry plant. http://asktheplant.com/fruiting-plants.

7. Anonymous (2010). Humic acid and fulvicacids: The black gold of agriculture. www.humintec.com/pdf/humicfulvicacid s.pdf (Access date: 10.08.2010).

8. Sharif, Sharif M, Khattak RA \& Sarir MS (2002). Wheat yield and nutrients accumulation as affected by humic acid and chemical fertilizers. Sarhad $J$ of Agric (Pakistan).

9. Khattak RA \& Muhammad D (2008). Increasing Crop Production through Humic Acid in Salt affected soils in kohat division (NWFP). Pak-Us Collaborative Research Endeavor, ALP Project, PARC, Islamabad.

10. Rengrudkij P \& Partida GJ (2003). The effects of humic acid and phosphoric acid on grafted Hass avocado on Mexican seedling rootstocks. In Actas $V$ Congreso Mundial del Aguacate 395400).

11. Tan KH (2003). Chemical composition of humic acid matter. Humic acids in soil and the environment. Principles and Controversies. Marcel and Dekker, New York. USA.

12. Jiu CF, Dao QY \& Quing SW (1995). Physiological effects of humic acid on drought resistance of wheat (in Chinese), Yingyong Shengtai Xuebao 6: 363-367.

13. AOAC (1990). Association of Official Agriculture Chemist) Official Methods of Analysis 9th, 832.

14. Zakaria M, Simpson K, Brown PR \& Krstulovic A (1979). Use of reversedphase high-performance liquid chromatographic analysis for the determination of provitamin A carotenes in tomatoes. $J$ of Chromatography A 176(1): 109-17.

15. Steel RGD, Torrie JH \& Dicky DA (1997). Principles and Procedures of Statistics: A Biometric Approach. 3rd ed. MCGRAW Hill Book Co. Inc. NewYork pp. 172 -177.

16. Chen Y, Aviad $\mathrm{T} \&$ MacCarthy $\mathrm{P}$ (1990). Presented at the humic substances in soil and crop sciences: selected readings Proceedings of a symposium cosponsored by the International Humic Substances Society, Chicago, Illinois.

17. Zhang $X$ \& Schmidt RE (2000). Hormone-containing products' impact on antioxidant status of tall fescue and creeping bentgrass subjected to drought. Crop Sci 40(5): 1344-1349.

18. HosseiniFarahi M, Aboutalebi A, Eshghi S, Dastyaran M \& Yosefim F (2013). Foliar application of humic acid on quantitative and qualitative characteristics of 'Aromas' strawberry in soilless culture. Agri Commun 1: 13-16.

19. Arancon NQ, Edwards CA, Lee $S \&$ Byrne R (2006). Effects of humic acids from vermicomposts on plant growth. Eurp J of Soil Bio 42: 65-69.

20. Muhammad S (2010). Production of Organic Wheat crop, 2008-2009. PARC report 1-22.

21. Arancon NQ, Lee S, Edwards CA \& Atiyeh R (2003). Effect of humic acids derived from cattle, food and paper waste vermicomposts on growth of green house plants.Urban and Fischer Verlag 47: 741-744.

22. Neri D, Lodolini EM., Savani G, SAbbatici P, Bonanmi G \& Zucconi F (2002). Foliar application of humic acids on strawberry (cv. Onda). Acta Hortic 594: 297-302.

23. Unlu H, Ozdamar UH \& Karakurt Y (2010). Influence of humic acid on the 
antioxidant compounds in pepper fruit. $J$ Food Agric Environ 8(3-4): 434-438

24. Trudel, MJ \& Ozbun JL. 1971. Influence of potassium on carotenoid content of tomato fruit. $J$ Amer Soc Hort Sd 96:763-765.

25. Karakurt Y, Unlu H \& Padem H (2009). The influence of foliar and soil fertilization of humic acid on yield and quality of pepper. Acta Agric Scandinavica Section B Plant Soil Sci 59 (3): 233-237

26. Mohammadipour E, Golchin A, Mohammadi J, Negahdar N \& Zarchini M (2012). Effect of humic acid on yield and quality of marigold (Calendula officinalis L.). Ann Biol Res 3: 50955098.

27. Archana PP, Theodore JKR, Ngyuen VH, Stephen TT \& Kristen AK (2009).
Vermicompost extracts influence growth, mineral nutrients, phytonutrients and antioxidant activity in pak choi (Brassica rapa cv. Bonsai Chinensis group) grown under vermicompost and chemical fertilizer. $J$ of Food Sci and Agri 89: 2383-2392.

28. Perez-Lopez AJ, Lopez-Nicolas JM, Nunez-Delicado E, Del Amor FM \& Carbonell-Barrachina AA (2005). Effects of agricultural practices on color, carotenoids composition, and minerals contents of sweet peppers. J Agric Food Chem 5: 8158-8164.

29. Aminifard $\mathrm{MH}$, Aroiee $\mathrm{H}$, Azizi M, Nemati H, Hawa Z \& Jaafar E (2012). Effect of humic acid on antioxidant activities and fruit quality of hot pepper (Capsicum annuum L.). J Herbs, Spices and Med Plants 18: 360-369. 